\title{
Aplikasi Media Pembelajaran Berbasis Serious Games (Games Education) untuk Belajar Menulis
}

\author{
Nunuk Wahyuningtyas ${ }^{1}$, Normaningsih ${ }^{2}$, Tri Sagirani* ${ }^{* 3}$ \\ ${ }^{1,2,3}$ Institut Bisnis dan Informatika Stikom Surabaya; Jl. Kedung Baruk 98 Surabaya, \\ Telp.0318721731 \\ ${ }^{1,2,3}$ Fakultas Teknologi dan Informatika \\ e-mail: ${ }^{1}$ nunuk@stikom.edu, ${ }^{2}$ norma@ stikom.edu, ${ }^{* 3}$ tris@ stikom.edu
}

\begin{abstract}
Developing serious games (games education) application for learning media with attention to user experience model for children with special needs becomes an important thing in learning creativity. Through learning of media application, it aims the learning process more interesting and improves learning motivation to raise up the children with Special Educational Needs (SEN), particularly to understand letters, numbers, simple words and learn how to write using the application of learning media and input device (such as pen tablet or touch screen). The utilization of learning media application to the students with special needs would be done through the measurement of User Experience Questionnaire (UEQ), and obtained the excellent value on application appeal, content clarity, efficiency and accuracy, and good value for stimulation and novelty. It can be concluded that the application of learning media based on the serious games for learning media to write can be used as learning tools.
\end{abstract}

Keywords: Learning Media, Serious Games, Children with Special Educational Need, User Experience

\begin{abstract}
Abstrak
Merancang dan membangun aplikasi serious games (games education) dengan memanfaatkan model user experience untuk mendukung pengembangan media belajar yang tepat bagi anak berkebutuhan khusus (ABK) kelompok tuna grahita ringan yang disesuaikan dengan keterbatasan dan kemampuan anak menjadi bagian penting dalam kreatifitas pembelajaran. Dengan penyusunan aplikasi media pembelajaran ini dapat membantu proses pembelajaran berjalan dengan lebih menarik dan dapat meningkatkan motivasi belajar dan kemandirian ABK tuna grahita khususnya dalam belajar mengenal huruf, angka, kata sederhana dan belajar menuliskannya dengan memanfaatkan aplikasi media pembelajaran berbasis serious games dengan berbantuan peralatan input berupa pen tablet atau touch screen. Dari pemanfaatan aplikasi media pembelajaran ini pada siswa berkebutuhan khusus dilakukan pengukuran memanfaatkan User Experience Questionnaire (UEQ) dan diperoleh nilai excellent pada daya tarik aplikasi, kejelasan konten, efisieni dan ketepatan, dan nilai good untuk stimulasi dan kebaharuan. Hal ini dapat disimpulkan bahwa aplikasi media pembelajaran berbasis serious games untuk belajar menulis sesuai untuk digunakan sebagai alat bantu dalam pembelajaran.
\end{abstract}

Kata kunci: Media Pembelajaran, Serious Games, Anak Berkebutuhan Khusus, User Experience 


\section{PENDAHULUAN}

Pemanfaatan Teknologi Informasi dan Komunikasi (TIK) dapat mendukung kreatifitas dalam pengembangan dan pemanfaatan media pembelajaran. Dalam penyusunan media pembelajaran dengan memanfaatkan TIK yang sesuai, tidak lepas dari interaksi manusia dan komputer (human computer interaction/HCI). Terdapat tiga hal utama yang menjadi perhatian dalam perkembangan HCI yaitu functionality, usability dan user experience [1]. Functionality terkait dengan masalah teknis terhadap fungsi-fungsi yang dapat dilakukan oleh sebuah produk teknologi. Usability berkaitan dengan karakteristis dari interaksi antara pengguna dengan produk teknologi. User experience berkenaan dengan pengalaman pribadi seorang pengguna dalam memanfaatkan produk teknologi yang ada.

Pengembangan pembelajaran dengan memanfaatkan media pembelajaran yang menarik dan sesuai dengan karakteristik anak berkebutuhan khusus (ABK) dapat memudahkan dalam penyampaian materi ajar oleh guru kepada siswanya. Dalam hal ini, pemanfaatan aplikasi komputer dalam bentuk games. Aplikasi games umumnya dianggap sebagai bentuk hiburan semata, namun sebenarnya games memiliki fungsi jauh lebih baik dari hanya sekedar hiburan belaka. Kombinasi dari tampilan yang menarik dan peraturan yang beragam, membuat games diminati oleh semua kalangan muda sampai tua tidak terkecuali ABK. Perkembangan pasar teknologi baru seperti smartphone, tablet, maupun hybrid PC yang lebih portabel, membuat games menjadi bagian yang perlu dikembangkan dalam memberikan dukungan pada proses pembelajaran yang sering kita kenal dengan Serious Games (Games Education). Tidak sedikit games yang dibuat dengan tujuan utama bukan sebagai hiburan, beberapa digunakan untuk proses pembelajaran yang membutuhkan kelebihan games dalam menyajikan tantangan dan sistem nilai sebagai penunjang pembelajaran. Games semacam ini disebut serious games dan dirancang untuk memecahkan beberapa masalah. Serious Games atau permainan digital memiliki beberapa keunggulan antara lain dibangun diatas prinsip-prinsip pembelajaran yang sehat, menyediakan banyak keterlibatan siswa dalam memainkannya, memberi kesempatan untuk belajar secara mandiri, menyediakan lingkungan permainan yang menyenangkan dan terdapat proses penilaian yang relevan [2]. Pengembangan pembelajaran dengan memanfaatkan media pembelajaran yang menarik tersebut dibutuhkan pemanfaatan teknologi komputer dalam meningkatkan kualitas pembelajaran bagi ABK. Pemanfaatan komputer yang sesuai dapat memudahkan dalam penyampaian materi ajar oleh guru kepada siswanya [3], juga dapat meningkatkan minat, hasil belajar, motivasi belajar siswa [4,5].

Pemanfaatan teknologi komputer dapat didukung juga dengan pemanfaatan peralatan input yang beragam, yang mampu mendukung media pembelajaran dapat dijalankan dengan lebih menarik [6] dan dapat memberikan pengalaman bagi penggunanya atau dikenal pula dengan istilah User Experience (UX). Pada kenyataannya dalam mendukung siswa belajar menulis bagi pemula khususnya bagi ABK, beberapa media yang digunakan selama ini baru sebatas pemanfaatan buku bergaris dengan tanda titik-titik untuk diikuti dengan pergerakan jari anak yang memegang pensil. Dalam pengembangan media pembelajaran yang akan disusun berupa aplikasi Serious Games (Games Education), usaha difokuskan pada pemanfaatan teknologi komputer berupa penyusunan aplikasi komputer untuk siswa belajar memulai membaca dan menulis dengan alat bantu berupa komputer dilengkapi dengan peralatan input pendukung berupa Drawing Pen dan Touchscreen untuk digunakan sebagai pengganti buku dan alat tulis dalam proses membiasakan pergerakan tangan dalam aktifitas menulis, mengulang dan memperbaiki hasil tulisan.

Dalam penelitian ini, pemanfaatan model UX [6] dalam merancang dan membangun sebuah aplikasi serious games (games education) yang akan diusulkan untuk pengembangan media pembelajaran bagi ABK tuna grahita yang memiliki beberapa keterbatasan. Keterbatasan yang dimiliki antara lain adalah perilaku keseharian yang tidak sesuai dengan kemampuan potensial yang mereka miliki, keterlambatan secara verbal [7], mengucapkan kata yang tidak mudah untuk dimengerti, keterlambatan dalam pemahaman dan penggunaan bahasa, juga 
mempunyai kelemahan dalam keterampilan gerak [4]. Keterbatasan yang lain adalah kurang mampu memusatkan perhatian saat belajar, beraktifitas dan mengikuti petunjuk serta kurang mampu untuk menghindarkan diri mereka dari bahaya yang ada. ABK tuna grahita lebih cepat lupa, dan sebagian anak cenderung pemalu, kurang kreatif dan tidak memiliki inisiatif, perbendaharaan katanya terbatas, dan memerlukan tempo belajar yang relatif lama dibandingkan anak normal [8].

\section{METODE PENELITIAN}

\subsection{Materi Penelitian}

Penelitian ini difokuskan pada merancang dan membangun aplikasi serious games (games education) dengan memanfaatkan model user experience [6] untuk mendukung pengembangan media belajar yang tepat. Model UX yang dimaksud digunakan sebagai acuan bagi pengembangan aplikasi dalam media pembelajaran untuk ABK tuna grahita ringan yang tentunya disesuaikan dengan keterbatasan dan kemampuan ABK. Dengan demikian pengembangan Model UX melalui penyusunan media pembelajaran ini dapat membantu proses pembelajaran berjalan dengan lebih menarik dan dapat meningkatkan motivasi belajar dan hasil belajar berupa kemandirian ABK tuna grahita khususnya dalam mengenal huruf, angka, kata sederhana dan menuliskannya memanfaatkan aplikasi media pembelajaran dengan peralatan input berupa pen tablet dan touch screen.

\subsection{Subyek Penelitian}

Subyek dalam penelitian ini adalah siswa Sekolah Dasar Luar Biasa (SDLB) dari kelompok tuna grahita ringan. Kelompok ini adalah kelompok tuna grahita yang mampu didik yaitu kelompok tuna grahita ringan yang memiliki kapasitas inteligensi (IQ) antara 50 - 70 [8]. Kelompok ABK ini masih mempunyai kemampuan untuk dididik dalam bidang akademik yaitu mengenal huruf, menulis huruf, menulis angka dan menulis beberapa kata dan kalimat sederhana. Penelitian ini merupakan penelitian eksperimen yang dilakukan terhadap subyek secara individual untuk melihat perubahan perilaku.

\subsection{Tahapan Penelitian}

Adapun tahapan dalam penelitian ini adalah sebagai berikut:

a. Tahap Investigasi Awal.

Tahap ini adalah pra pembuatan model yang akan dikaji ialah mengembangkan model UX untuk ABK [6] dalam pemanfaatan TIK dalam media pembelajaran. Dalam tahap ini dilakukan kajian terhadap pemanfaatan media dalam pembelajaran, UX dalam aplikasi baik secara umum maupun khusus bagi ABK, beberapa kajian terhadap literatur terkait, kurikulum dan standar kompetensi SLB serta penelitian-penelitian pendahulu yang terkait hingga menghasilkan model konseptual. Selain itu dalam tahap ini juga dilakukan identifikasi karakteristik ABK tuna grahita ringan, komponen UX dan identifikasi trend teknologi dalam pendidikan ABK.

\section{b. Tahap Desain.}

Tahap Desain disebut juga tahap pengembangan model menjadi desain antarmuka pengguna. Pada tahap ini model akan dirancang dalam aplikasi serious games (games education) sebagai media pembelajaran bagi ABK. Rancangan desain memperhatikan hasil identifikasi konten, cara menyajikan, fungsionalitas media yang dibutuhkan oleh $\mathrm{ABK}$, interaksi yang dapat mendukung pembentukan pengalaman dalam belajar, kepuasan dalam proses belajar siswa dan identifikasi tentang keamanan dan kenyamanan dari pemanfaatan media bagi ABK tuna grahita ringan dengan segala keterbatasannya. 
Hasil yang diperoleh dari tahap ini adalah rancangan atau desain aplikasi serious games (games education) yang dapat meningkatkan stimulus dalam media pembelajaran. Desain ini selanjutnya akan dituangkan dalam prototype aplikasi media pembelajaran pada tahap realisasi.

\section{c. Tahap Realisasi.}

Pada tahap ini disusun suatu prototype aplikasi serious games (games education) sebagai lanjutan dari tahap desain. Kegiatan yang dilakukan pada tahap ini mencakup kegiatan Software Development Life Cycle (SDLC) dalam pengembangan sebuah aplikasi. Model SDLC yang digunakan adalah model waterfall yang meliputi tahapan analisa kebutuhan, mendesain sistem, menyusun aplikasi/coding dengan memanfaatkan software Unity, melakukan testing dan pemanfaatan di lapangan. Analisa kebutuhan untuk penyusunan aplikasi media pembelajaran bagi pengguna dalam hal ini adalah $\mathrm{ABK}$ mengacu pada kebutuhan akan dukungan media pembelajaran untuk mata pelajaran bahasa Indonesia khususnya untuk materi menulis yang didasarkan pada KTSP Tahun 2006 SDLB Tuna grahita Ringan (SDLB-C) [9] dengan mengacu pada standar kompetensi dan kompetensi dasar SDLB-C Tahun 2006 [10]. Penyusunan aplikasi difokuskan pada pemahaman yang ingin dicapai pada ABK dengan mengukur beberapa kemampuan siswa yaitu kemampuan menulis angka, huruf dan kata sederhana. Gambar 1 berikut ini adalah gambaran tahapan dalam penyusunan aplikasi untuk media pembelajaran.

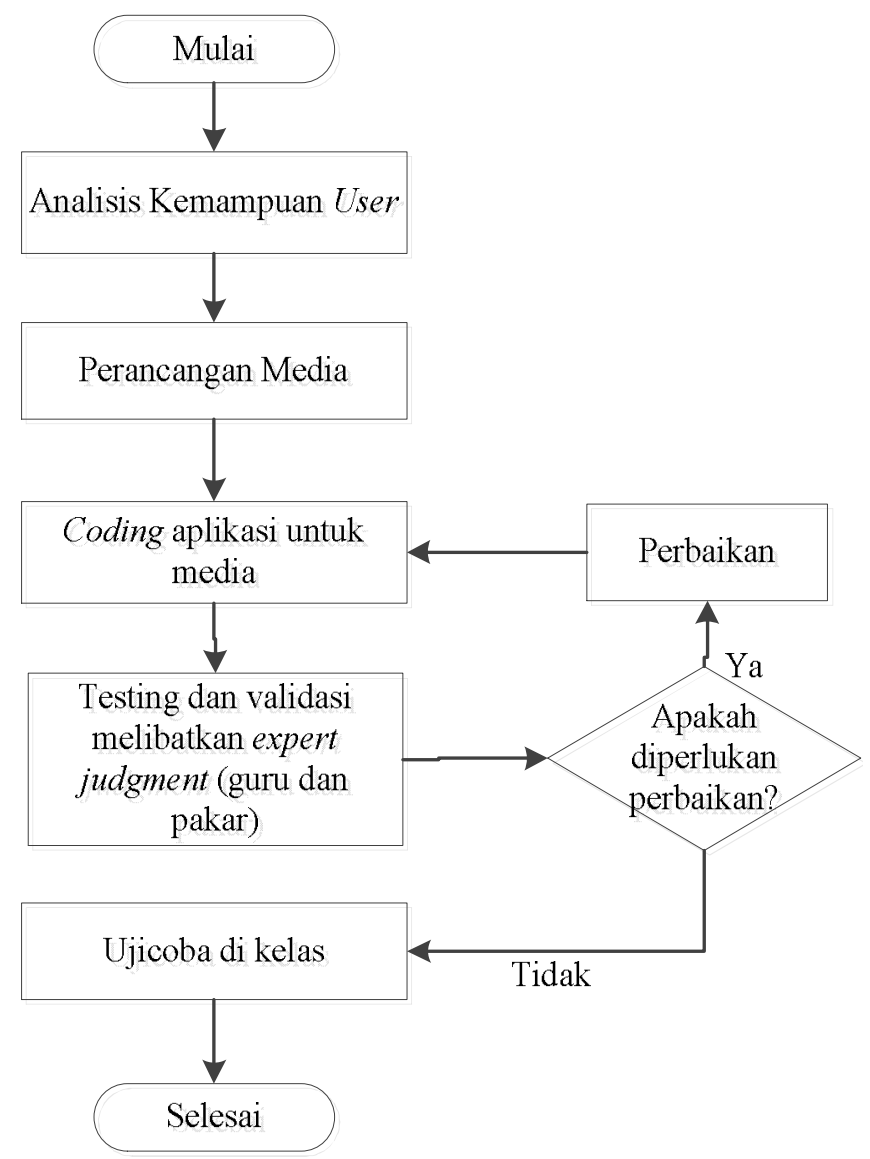

Gambar 1. Diagram Alir Penyusunan Aplikasi

d. Tahap Tes, Evaluasi dan Revisi.

Tahap ini difokuskan pada penilaian pada fokus User Experience pada ABK mengacu pada User Experience Questionnaire (UEQ). Kuisioner ini terdiri dari pasangan atribut yang bertolak 
belakang secara makna yang dapat mempresentasikan produk atau aplikasi media pembelajaran yang disusun [11]. Pencatatan hasil belajar siswa melalui latihan yang disediakan dalam aplikasi media pembelajaran. Proses validasi, pengamatan dan interview pada siswa dengan bantuan/pendampingan oleh guru dengan menggunakan UEQ.

Data yang akan didapat terkait pengukuran terhadap peningkatan kemampuan ABK meliputi enam variabel yang akan dievaluasi, yaitu menulis huruf/angka, dan kata. Evaluasi untuk variabel yang ada menggunakan sistem skoring dengan skala likert. Semua jawaban siswa dengan bantuan guru saat interview akan dikonversi dengan pendekatan pada rentang skor 1-7.

\section{HASIL DAN PEMBAHASAN}

Penelitian ini memanfaatkan model UX yang telah ada [6] dan menyusun prototype aplikasi media pembelajaran berbasis serious games yang selanjutnya dimanfaatkan oleh ABK dalam proses belajar membaca kata sederhana dan belajar menulis. Model yang digunakan dapat dilihat pada Gambar 2.

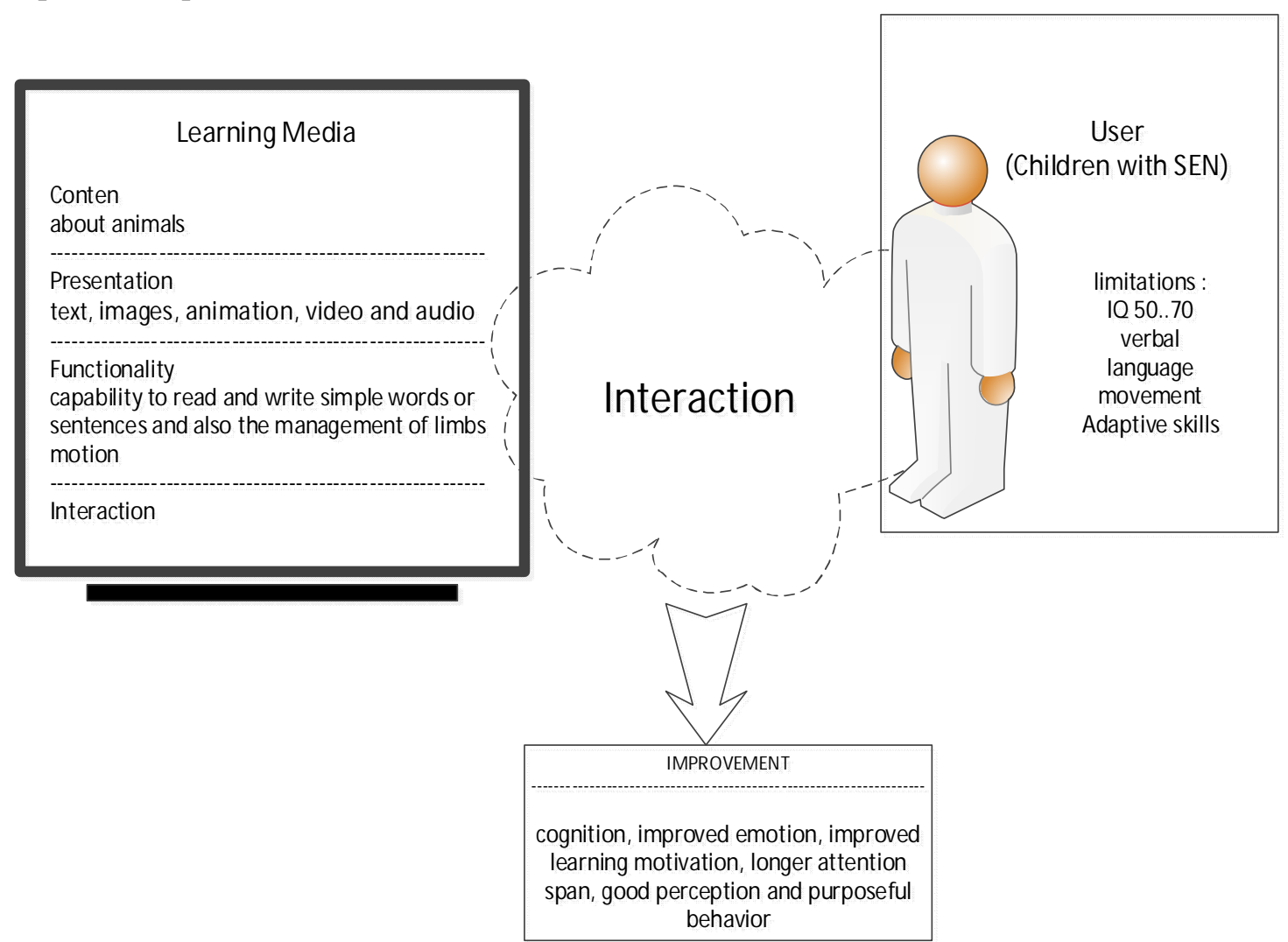

Gambar 2. User Experience Model (Sagirani et al, 2015)

Dari model yang ada pada gambar 2 selanjutnya disusun prototype aplikasi media pembelajaran dengan memanfaatkan serious games. Tabel 1 berikut ini adalah identifikasi dari model interaksi antara media pembelajaran berbasis serious games dengan pengguna dan peralatan yang digunakan.

Tabel 1: Identifikasi dari Model Interaksi

\begin{tabular}{ll}
\hline \multicolumn{1}{c}{ Aktifitas } & \multicolumn{1}{c}{ Pendukung } \\
\hline Konten & $\bullet$ Materi: belajar menulis dan membaca kata sederhana \\
& $\bullet$ Penyajian: visualisasi huruf, suara untuk mendengar bacaan \\
\hline
\end{tabular}




\begin{tabular}{ll}
\hline & - Fungsionalitas: mengenal huruf dan kata/ kalimat sederhana \\
& - Interaksi: user menulis dan membaca \\
& Memiliki keterbatasan: \\
• & IQ 50..70 \\
& - Verbal \\
& - Bahasa \\
& - Gerak \\
& - Keterampilan Adaptif \\
& - Laptop \\
- Proyektor & - Mouse \\
- Keyboard \\
- Touch Screen \\
- Drawing Pen
\end{tabular}

Langkah berikutnya untuk penyusunan prototype dengan diawali menyusun design antarmuka aplikasi serious games yang dapat mendukung ketersediaan media pembelajaran. Salah satu prinsip dalam mendesain adalah adanya pertimbangan untuk melengkapi atau meningkatkan motivasi dan proses belajar [12,13,14].

Desain terkait dengan motivasi. maka terdapat 5 hal yang menjadi pertimbangan dalam mendesain aplikasi media pembelajaran yaitu:

1. Aplikasi media pembelajaran disusun dengan mengalir yaitu menjadikan hasil desain menjadi lebih menyenangkan bagi pengguna dengan tantangan yang disesuaikan dan terdapat beberapa tingkatan tugas.

2. Aplikasi media pembelajaran hendaknya disusun untuk menumbuhkan rasa ingin tahu dari pengguna.

3. Aplikasi media pembelajaran disusun dengan otonomi pengguna yaitu pengguna memiliki kontrol terhadap aktivitas yang mereka lakukan.

4. Aplikasi media pembelajaran mampu memberikan ungkapan atas keberhasilan pengguna dalam menjalankan aktivitas, hal ini dapat memperkuat motivasi pengguna dan biasanya disimbolkan dengan tanda bintang sesuai dengan keberhasilan tiap-tiap pengguna.

5. Aplikasi media pembelajaran dapat memberikan umpan balik, hendaknya desain menyediakan umpan balik berupa jawaban dari setiap soal yang dberikan.

Pertimbangan kedua dalam prinsip mendesain aplikasi media pembelajaran adalah aktivitas dalam proses belajar, yaitu meliputi:

1. Tanya-Jawab, pengguna dapat memecahkan soal yang ditampilkan dengan memberikan jawaban atas setiap pertanyaan/tugas menggunakan drawing pen untuk menulis.

2. Instruksional/bimbingan, pengguna mendapatkan tantangan dengan topik yang berbeda, seperti menulis angka, menulis huruf kapital, menulis huruf kecil hingga menulis kata.

3. Pengulangan dan refleksi, aplikasi memberikan penguatan dan membangun pengetahuan pengguna.

4. Aksi/Tugas, aplikasi media pembelajaran memberikan kegiatan belajar yang membutuhkan partisipasi aktif antara pengguna dengan media pembelajaran.

5. Penilaian diri, pengguna dapat mengevaluasi dirinya sendiri dengan menjawab pertanyaan yang disediakan.

Dengan menyadari pertimbangan terhadap motivasi dan proses pembelajaran yang hendak didapat maka berikut ini adalah tampilan dari aplikasi media pembelajaran berbasis serious games. Pengguna bisa belajar menulis sesuai intruksi yang diberikan dan menjawab 
dengan menggunakan drawing pen atau menunjuk dan menggerakkan jari saat menggunakan layar sentuh.

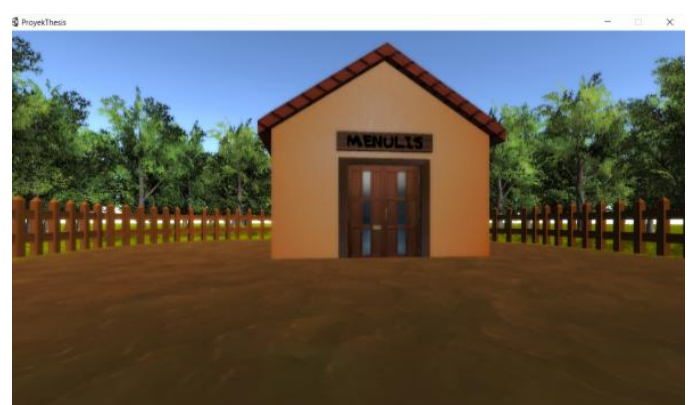

(1) Tampilan utama fisik gedung sekolah

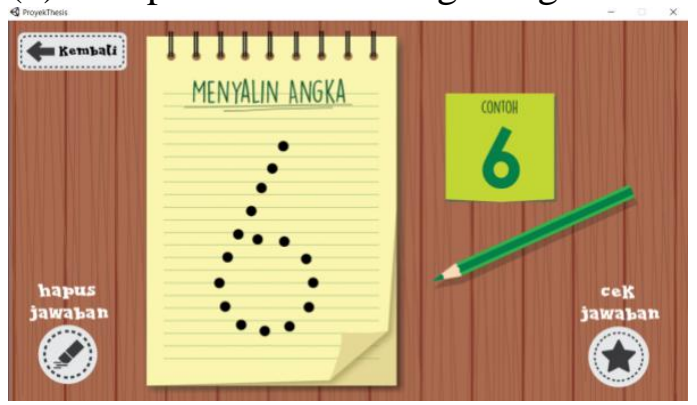

(3) Materi menulis angka

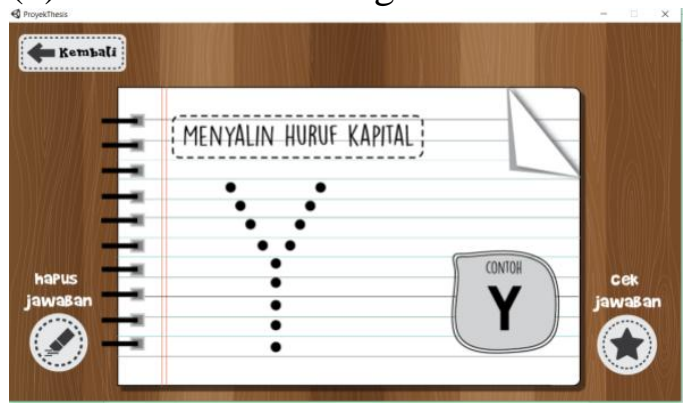

(5) Materi menulis huruf kapital

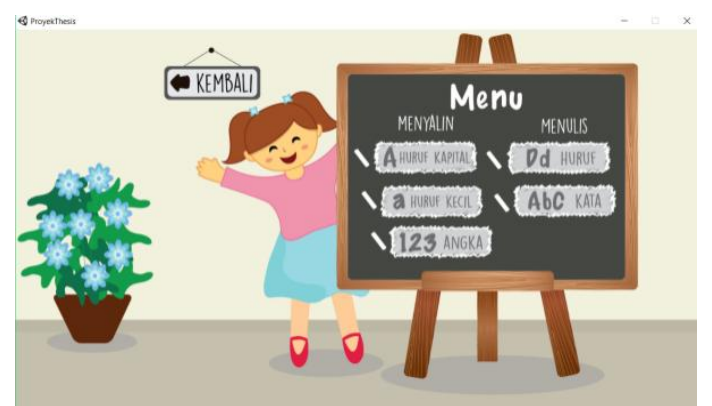

(2) Pilihan menu sesuai level

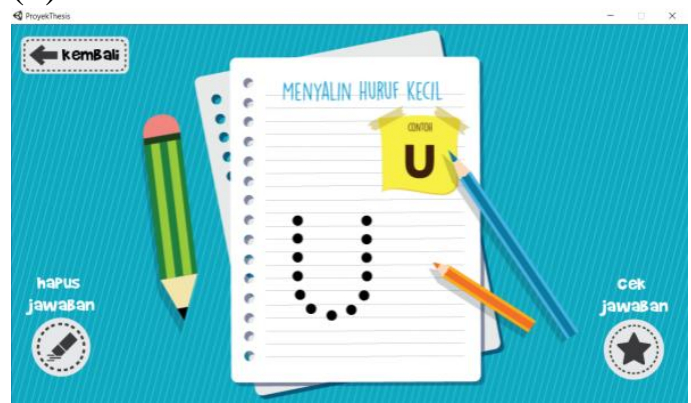

(4) Materi menulis huruf kecil

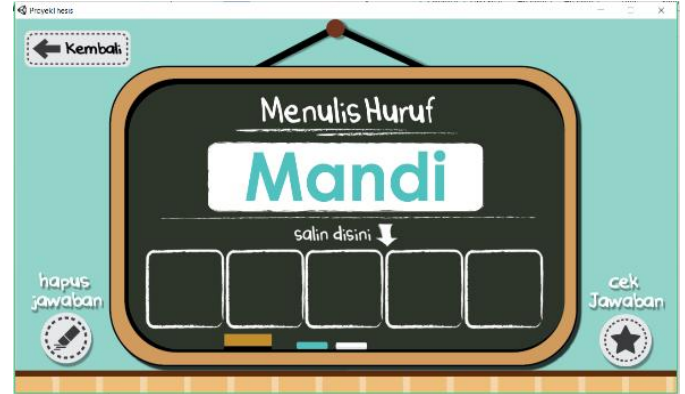

(6) Materi menulis kata sederhana

Gambar 3. Desain Antarmuka Aplikasi Media Pembelajaran

Uji coba telah dilakukan pada siswa dan selanjutnya dilakukan pencatatan hasil interview pada siswa dengan didampingi oleh guru. Alat ukur yang digunakan dengan memanfaatkan User Experience Questionnaire [11]. Terdapat 26 point dalam kuisioner yang kemudian dikelompokkan menjadi 6 point yaitu daya tarik, kejelasan, efisien, ketepatan, stimulasi dan kebaharuan. Dari hasil pengisian data dengan 48 responden (siswa) dengan didampingi oleh guru, menghasilkan perhitungan sebagai berikut:

Tabel 2. Hasil User Experience Questionnaire

\begin{tabular}{lccccccc}
\hline \multicolumn{1}{c}{ Scale } & $\begin{array}{c}\text { Lower } \\
\text { Border }\end{array}$ & Bad & $\begin{array}{c}\text { Below } \\
\text { Average }\end{array}$ & $\begin{array}{c}\text { Above } \\
\text { Average }\end{array}$ & Good & Excellent & Mean \\
\hline Daya tarik & $-1,00$ & 0,65 & 0,44 & 0,41 & 0,22 & 0,78 & 1,91 \\
Kejelasan & $-1,00$ & 0,53 & 0,37 & 0,47 & 0,45 & 0,68 & 1,93 \\
Efisiensi & $-1,00$ & 0,5 & 0,34 & 0,47 & 0,33 & 0,86 & 1,78 \\
Ketepatan & $-1,00$ & 0,7 & 0,36 & 0,34 & 0,2 & 0,9 & 1,68 \\
\hline
\end{tabular}




\begin{tabular}{llllllcl}
\hline Stimulasi & $-1,00$ & 0,52 & 0,48 & 0,31 & 0,19 & 1 & 1,56 \\
Kebaruan & $-1,00$ & 0,24 & 0,39 & 0,33 & 0,38 & 1,16 & 1,06 \\
\hline
\end{tabular}

Dengan demikian hasil pengolahan data User Experience Questionnaire dapat disampaikan dalam Gambar 4 sebagai berikut ini:

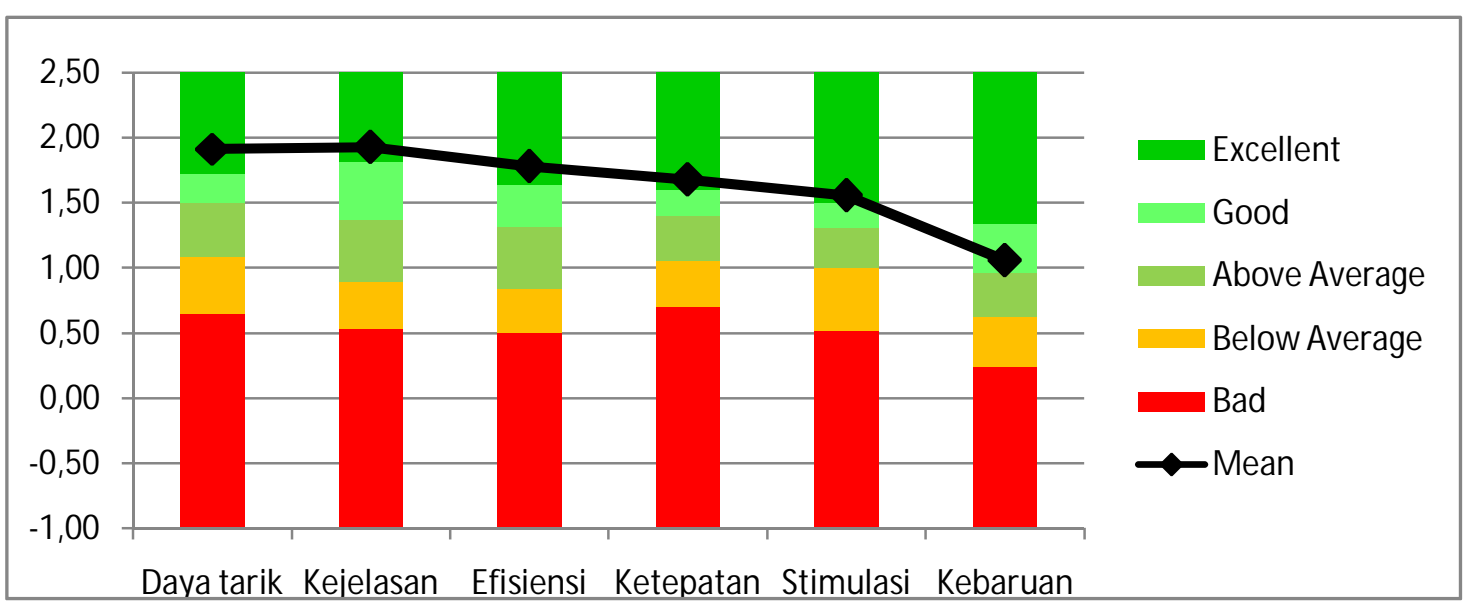

Gambar 4. Grafik Hasil User Experience Questionnaire

\section{KESIMPULAN}

Dari uraian di atas, penelitian tentang pemanfaatan aplikasi media pembelajaran berbasis serious games (games education) untuk belajar menulis dapat disimpulkan bahwa:

1. Penelitian ini menghasilkan pengembangan media pembelajaran yang lebih menarik untuk belajar menulis. Media pembelajaran yang menarik dapat meningkatkan kemauan dan kemampuan dalam belajar siswa, hal ini menjadi salah satu komponen pendukung keberhasilan belajar ABK.

2. Aplikasi media pembelajaran berbasis serious games untuk media belajar menulis sesuai untuk digunakan sebagai alat bantu dalam pembelajaran. Hal ini dibuktikan dengan nilai pada daya tarik dari aplikasi memiliki nilai mean 1,91 (excellent), kejelasan konten dengan nilai mean 1,93 (excellent), efisien dengan nilai mean 1,78 (excellent), dan ketepatan dengan nilai mean 1,68 (excellent). Sedangkan stimulasi dan kebaharuan masing-masing memiliki nilai mean berturut-turut 1,56 dan 1,06 (good)

\section{SARAN}

Keberhasilan dalam memberikan pengalaman pengguna dalam memanfaatkan aplikasi media pembelajaran juga dapat dipengaruhi dengan peralatan input yang digunakan, selanjutnya dapat dikembangkan kembali pemanfaatan peralatan input yang lain yang memungkinkan untuk dapat digunakan oleh ABK. Aplikasi media pembelajaran berbasis serious games juga dapat dikembangkan lebih lanjut untuk materi belajar yang lain dan kelompok ABK yang lain pula, agar kesenjangan pemanfaatan teknologi informasi dapat dirasakan oleh anak-anak yang memiliki keterbatasan tertentu. 


\section{DAFTAR PUSTAKA}

[1] McNamara, N., Kirakowski, J 2006, Functionality, Usability, and User Experience: Three Areas if Concern, Mag, Interact. - Waits Meas.

[2] Katie Larsen McClarty, Aline Orr, Peter M. Frey, Robert P. Dolan, Victoria Vassileva, Aaron McVay 2012, A Literature Review of Gaming in Education, Pearson.

[3] Sagirani, T., Ferdiana, R., Kumara, A 2013, The Framework of Learning Media Development for The Children with Special Need, IEEE International Conference in MOOC, Innovation and Technology in Education (MITE).

[4] Bandi Delphi 2010, Pembelajaran Anak Tunagrahita (Suatu Pengantar dalam Pendidikan Inklusi), Refika Aditama- Bandung, pp. 20 - 39

[5] Smith, H. J., Higgins, S., Wall, K., \& Miller, J 2005, Interactive Whiteboards: Boon or Bandwagon? A Critical Review of Literature, Journal of Computer Assisted Learning.

[6] Sagirani, T., Nugroho, L.E., Santosa, P. I., Kumara, A 2015, User Experience Model in The Interaction Between Children with Special Educational Needs and Learning Media, Proceeding of 2nd International Conference on Information Technology, Computer and Electrical Engineering (ICITACEE), October 16-18, 2015, Semarang, Indonesia.

[7] Amin, M 1995, Ortopedagogik Anak Tunagrahita, Dirjen Dikti Depdikbud PPTG, Jakarta.

[8] Daniel P. Halahan, James M. Kauffman, Paige C. Pullen 2012, Exceptional Learners an Introduction to Special Education, pp. 104, Pearson Education, New Jersey.

[9] Departemen Pendidikan Nasional 2006, Standar Isi, Standar Kompetensi Lulusan dan Panduan Penyusunan KTSP Tunagrahita Ringan (C), Direktorat Pembinaan Sekolah Luar Biasa.

[10] Departemen Pendidikan Nasional 2006, Standar Kompetensi dan Kompetensi Dasar $S D L B-C$, Direktorat Pembinaan Sekolah Luar Biasa.

[11] Rauschenberger, M., Olschner, S.; Cota, M.P.; Schrepp, M., Thomaschewski, J 2012, Measurement of User Experience: A Spanish Language Version of The User Experience Questionnaire (UEQ), Information Systems and Technologies (CISTI), 7th Iberian Conference.

[12] Arnab,S., Lim, T., Carvalho, M.B., Bellotti, F., de Freitas, S., Louchart, S., Suttie, N., Berta, R., De Gloria, A 2014, Mappling Learning and Game Mechanics for Serious Game Analysis, British Journal of Educational Technology.

[13] Chua, A.Y.K., Balkunje, R.S 2012, An Exploratory Study of Game-based Mlearning for Software Project Management. Journal of Universal Computer Science, Vol. 18, No. 14, pp. 1933-1949.

[14] Mateos, M. J., Muñoz-Merino, P. J., Kloos, C. D 2016, Design and Evaluation of A Computer Based Game for Education, IEEE Frontiers in Education Conference (FIE) 